\title{
A STUDY ON BIOCHEMICAL CHANGES IN THE FRESH WATER FISH, CATLA CATLA (HAMILTON) EXPOSED TO THE HEAVY METAL TOXICANT CADMIUM CHLORIDE
}

\author{
Sobha, K., Poornima, $\mathbf{A}^{1}$., Harini, $\mathbf{P}^{1}$., Veeraiah, $\mathbf{K}^{2}$. \\ ${ }^{1}$ Department of Biotechnology, Bapatla Engineering College, Bapatla -522 101, \\ Guntur Dt., Andhra Pradesh, India. \\ ${ }^{2}$ Department of Zoology, Acharya Nagarjuna University, Nagarjuna nagar - 520 010, \\ Guntur Dt., Andhra Pradesh, India. \\ Corresponding Author E-Mail: sobha_kota@yahoo.co.in
}

\begin{abstract}
Cadmium $(\mathrm{Cd})$, one of the twenty three heavy metal toxicants, is widely used in Ni-Cd batteries manufacture, metal and mining industry, dentistry etc. because of its non-corrosive nature. $\mathrm{Cd}$ is released in considerable amounts through industrial effluents into soil, surface and ground water systems. These excess amounts in addition to naturally occurring levels gradually build up to toxic levels causing damage to the biota of the aquatic ecosystem. It shows biomagnification and has greater half-life periods. $\mathrm{Cd}$ was found to interfere with many protein and carbohydrate metabolisms by inhibiting the enzymes involved in the processes. The present study evaluates toxicity of $\mathrm{Cd}$ and its impact on biochemical constituents like glucose, glycogen, total proteins, lipid and free aminoacids in the fresh water edible carp Catla catla as Cd bioaccumulation can affect humans through biomagnification. Short term tests of acute toxicity were performed over a period of 96 hours using cadmium chloride. The renewal technique was followed by exposing the fish to test solutions of different concentrations in the range of $1 \mathrm{mg} / \mathrm{L}$ to $8 \mathrm{mg} / \mathrm{L}$. Preliminary experiments were conducted to choose concentrations that resulted in the mortality of the fish in the range of $10-90 \%$. The toxicity experiments were then conducted using the chosen concentrations of $\mathrm{CdCl}_{2}$ on the fingerlings ( Wt. $6 \pm 1$ grams ) in triplicate and the $\mathrm{LC}_{50}$ was determined using simple graphic ( \% Mortality Vs. Log Concentration), probit graphic ( Probit value Vs. Log concentration) and unweighted regression analysis methods. The calculated average 96-hr $\mathrm{LC}_{50}$ is $4.533 \mathrm{mg} / \mathrm{L}$ and the equation for the dose-mortality regression line was found to be $\mathrm{Y}=2.65 \mathrm{X}+3.368$. Levels of the five biochemical constituents viz., Glucose, Glycogen, Total proteins, Lipids and Free aminoacids were determined by standard biochemical procedures in the five tissues i.e., muscle, gill, liver, heart and kidney of unexposed (Control) healthy fish and the fish exposed to $96-\mathrm{hr} \mathrm{LC}_{50}$ (Lethal) and sub-lethal concentrations $\left(1 / 10^{\text {th }}\right.$ of the lethal dose for 7 days of exposure) of cadmium chloride. Results showed significant fall in all the biochemical constituents in all the tissues except glucose prompting to suggest that the fish cultured in the aquatic systems closer to the industrial locations would not have the expected nutritive value. The elevated levels of glucose are apparently indicative of the organism's response to the toxicant stress. Also, such fish when consumed as food lead to the deposition of the heavy metal in the soft tissues of the human body leading to exposure health effects.
\end{abstract}

Key words: Toxicity, Heavy metal, Cadmium chloride, Biomagnification, Catla catla 


\section{INTRODUCTION}

Among several elements of the periodic table, there are 35 metals are assoiciated with community and occupational exposure. Out of these, 23 are described as heavy metals. These elements are generally released in small amounts into the environment by processes like weathering of rocks, volcanic eruptions etc. and their intake/exposure is necessary in trace amounts for good health. But, presently, there is a steady increase in their concentration in all habitats owing to mining, electroplating, paints and dye, battery making industries etc. The release is rapid with the rapidly growing technology and heavy metal application in these industries. The two most important factors that contribute to the deleterious effects of heavy metals as pollutants are their indestructible nature through bioremediation unlike organic pollutants and their tendency to accumulate in environment especially in the bottom sediments of aquatic habitats in association with organic and inorganic matter. Out of the several heavy metals in the industrial waste streams (Forstner and Prosi, 1979), Cadmium is reported to be associated with the effluents of battery, electroplating and metal finishing, mining and metallurgy and paints and dye industries. The present study was attempted as these industries are well established in the Guntur District of Andhra Pradesh, India and the chosen experimental fresh water fish is a highly priced food item cultured largely in the coastal districts of Andhra Pradesh.

Cadmium (Cd) is a well known heavy metal toxicant with a specific gravity 8.65 times greater than water (Lide, 1992). Heavy metals become toxic when they are not metabolized by the body and accumulate in the soft tissues. The target organs for Cd toxicity have been identified as liver, placenta, kidneys, lungs, brain and bones (Roberts, 1999). The reported symptoms of acute $\mathrm{Cd}$ toxicity in human beings include nausea, vomiting, abdominal pain and breathing difficulty. Chronic exposure to $\mathrm{Cd}$ can result in obstructive lung disease, renal disease and fragile bones. Symptoms of chronic exposure may also include alopecia, anaemia, arthritis, learning disorders, migraines, growth impairment, osteoporosis, emphysema and cardiovascular diseases. If the laboratory testing procedures indicate blood levels of cadmium above $5 \mathrm{mcg} / \mathrm{dL}$ and creatinine levels in urine above $10 \mathrm{mcg} / \mathrm{dL}$, then it can be considered to be suggestive of Cd toxicity (Dupler, 2001).

Cadmium(Cd), one of the non-essential heavy metals, known for its non-corrosive nature is widely used in paints and dyes, cement and phosphate fertilizers (Jarrup, 2003). Cd occurs naturally in the environment, in insignificant amounts but its release in the recent past is steadily increasing due to human activities causing pollution of soil and aquatic systems. The occurrence of $\mathrm{Cd}$ in considerably toxic amounts was reported by earlier workers in various aquatic ecosystems (Bryan and Langston, 1992; Arno Kaschl et al., 2002; Audrys et al., 2004; Chrastny et al., 2006; BR Kiran et al., 2006). Cd was found to be teratogenic, embryotoxic, carcinogenic, nephrotoxic in humans and the risk is greater among smokers (Sunderman et al., 1991; Luo SQ et al., 1993). Cd can be taken up from the environment into the body through pulmonary and enteric pathways. $\mathrm{Cd}$, like many other heavy metals, is antagonistic to essential trace elements like $\mathrm{Fe}^{2+}, \mathrm{Zn}^{2+}, \mathrm{Cu}^{2+}, \mathrm{Ca}^{2+}$ etc. (Wright and Frain, 1981) and compete with nutrient elements for binding sites as transport and storage proteins, metalloenzymes and receptors. It acts as a stressor, leading to metabolic alterations similar to those observed in starvation conditions. It was reported that cadmium specifically inhibits some proteins like phosphofructokinase, lactate dehydrogenase etc and retards glycolysis. It also affects the glycogen and lipid levels of the organism. The toxicity of $\mathrm{Cd}$ is attributed to its ability to generate reactive oxygen species that may act as signaling molecules in the induction of gene expression and apoptosis ( Waisberg et al., 2003), deplete endogenous 
radical scavengers, and also damage a variety of transport proteins including the $\mathrm{Na}^{+} / \mathrm{K}^{+}$ATPase.

Cadmium, as other toxic metals, may set up conditions that lead to inflammation in arteries and tissues, causing more $\mathrm{Ca}^{2+}$ to be drawn to the area as a buffer, contributing to hardening of the artery walls with progressive blockage of the arteries and result in osteoporosis. Bioenhancement of Cd transfer along a food chain was studied by Seebaugh et al.(2005) and fish are reported to be used as biological indicators to assess water pollution (Rashed, 2001). In aquatic systems, as fish occupy the upper trophic level, there are greater chances of transferring $\mathrm{Cd}$ to higher organisms particularly to man.

Catla catla (Hamilton) is one of the major fresh water carps native to India, Bangladesh, Myanmar, Nepal, Pakistan and introduced in many other countries as exotic species. $C$. catla is a very rich source of proteins and is reported to attain a maximum size of $182 \mathrm{~cm}$ and weight of about 50 Kilograms (these figures vary ). It is a surface and mid-water feeder, mainly omnivorous with juveniles feeding on aquatic and terrestrial insects, detritus and phytoplankton. It has a characteristically large, upturned mouth with a prominent protruding jaw. Because of its high nutritive value, it is a highly priced food fish and of great demand in the market.

\section{MATERIALS AND METHODS}

Catla catla fingerlings (average weight: 6-7 grams) used in the present study were collected from the local fish farm located at Nandivelugu, Guntur Dt. , Andhra Pradesh, India and acclimatized to the laboratory for about a week in plastic pools of 50 liters capacity. Ground water used for maintaining the fish in the fish tanks had a $\mathrm{pH} 7.2 \pm 0.1$, dissolved oxygen $8.0 \pm 0.3 \mathrm{mg} / \mathrm{L}$ and bicarbonates $95.0 \pm 5.0 \mathrm{mg} / \mathrm{L} . \mathrm{LC}_{50}$ was determined by following Renewal bioassay and was calculated by Finney(1971) probit analysis method.

The biochemical constituents viz., Glucose, Glycogen, Total proteins and Free amino acids were estimated by standard procedures in 5 tissues viz., Muscle, Gill, Liver, Heart and Kidney of the healthy fish (Control) and of those from the fish exposed to sub-lethal and lethal concentrations of Cadmium chloride (Merck). One-tenth of the lethal concentration was taken as sub-lethal dose and the fish were exposed to sub-lethal dose for a period of 7 days before sacrifice for the biochemical analysis. The carbohydrates, proteins, lipids, and free aminoacids were estimated by methods of Kemp et al.(1954), Lowry et al.(1951), Moore and Stein (1954) and Pande et al.(1963) respectively.

\section{RESULTS AND DISCUSSION}

Fig. 1 depicts the percentage mortality for different exposure periods at different concentrations of cadmium chloride. $\mathrm{LC}_{50}$ value of cadmium chloride for the fish $C$. catla was determined by the simple graphic method ( Fig. 2 ), Probit graphic method ( Fig. 3 ) and the unweighted regression method (Finney, 1971 ) and the values from the three methods are $4.57 \mathrm{mg} / \mathrm{L}, 4.89 \mathrm{mg} / \mathrm{L}$ and $4.13 \mathrm{mg} / \mathrm{L}$ respectively. Hence the calculated average $\mathrm{LC}_{50}$ is $4.533 \mathrm{mg} / \mathrm{L}$. The equation for the dose-mortality regression line was found to be $\mathrm{Y}=2.65 \mathrm{X}+$ 3.368 . 
Fig. $1 \%$ Mortality Vs Exposure time

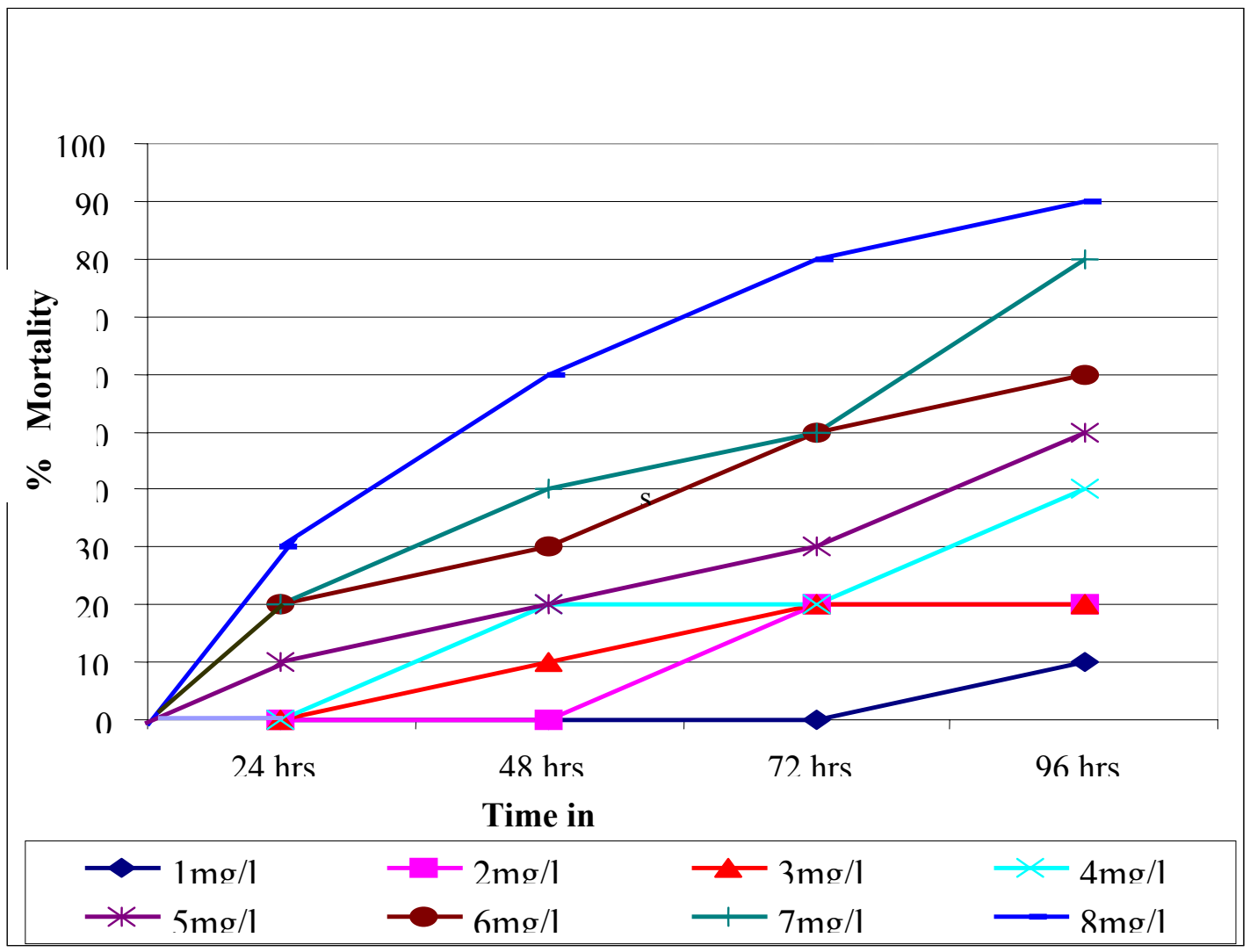

Fig. 2 Simple graphic method

( Log conc. Vs \% mortality )

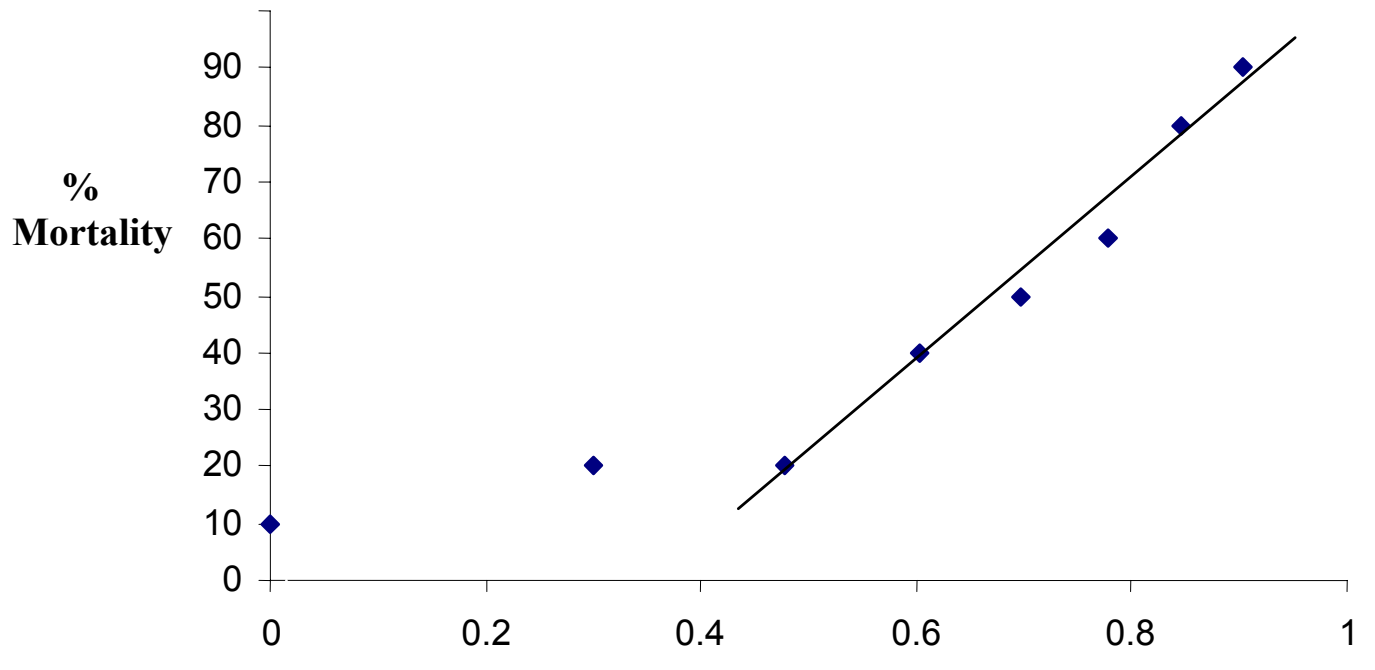


Fig. 3 Probit Graphic Method

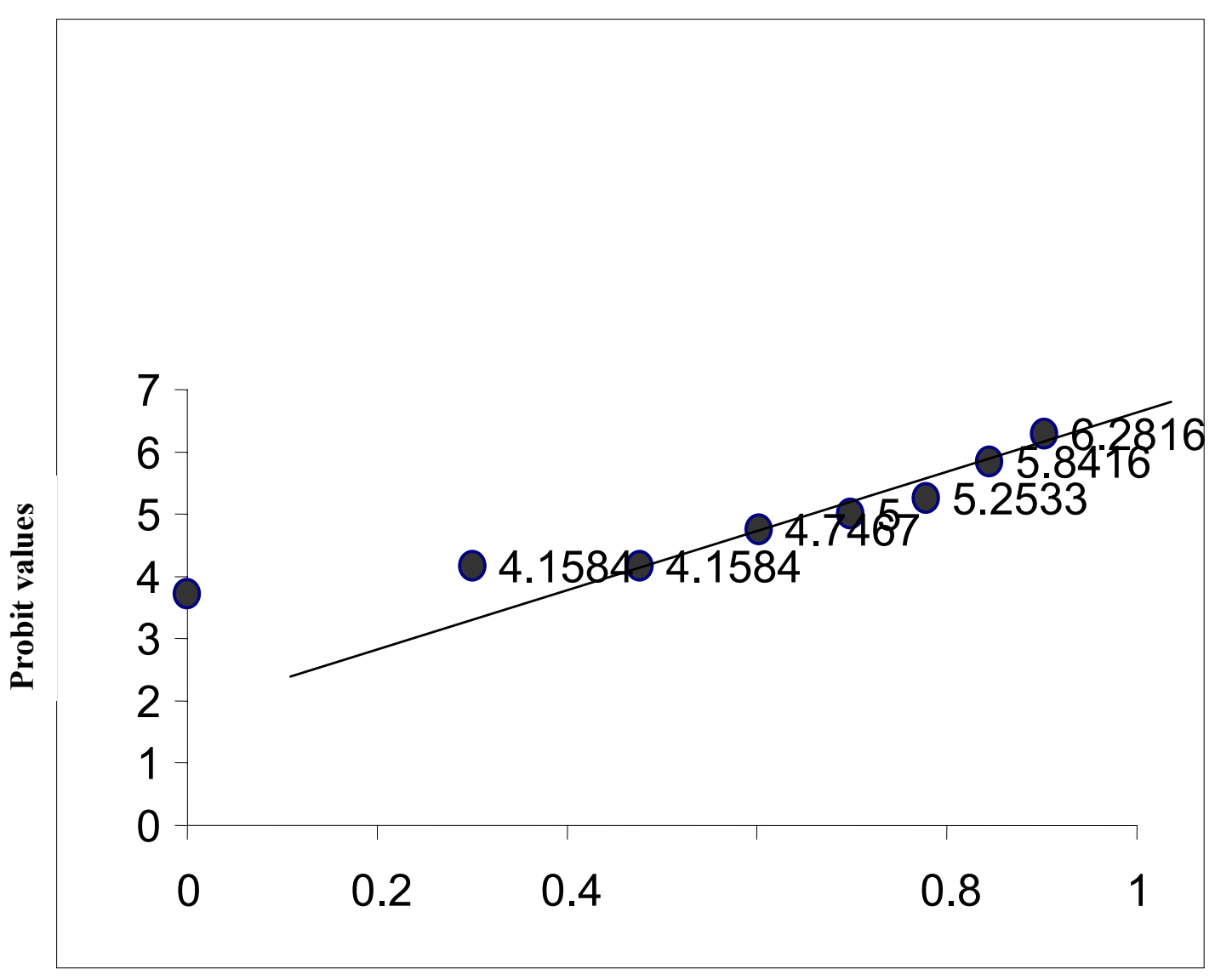

Log Concentration

The behaviour and mortality rate of $C$. catla during our experimentation was found to depend on both duration of exposure and concentration of the toxicant. C. catla are very sensitive than some of the other fish and crabs. This is evident from the reported values of $96 \mathrm{hr}$ $\mathrm{LC}_{50}$ for Poecili reticulata which is $30.4 \mathrm{mg} / \mathrm{L}$ in a static bioassay test system (Mehmet Yilmaz et al., 2004), $43 \mathrm{mg} / \mathrm{L}$ for Uca rapax (Zanders and Rojas, 1996), $25 \mathrm{mg} / \mathrm{L}$ for scorpion fish, Scorpaena guttata ( Brown DA et al., 1984). The effect of the metal also depends on the size of the animal, salinity of water, temperature and the type of the animal. Though the organisms survive the initial attack of toxins/pollutants because of their protective adaptations, the injuries caused by the progressive exposure even in small doses will get manifested at later stages when the organism's resistance weakens due to ageing. Also, the condition and response of the test organism to the amount of metal penetrating into its body, the degree of retention and the rate of excretion influence the toxic effect of heavy metal. 
Fig. 4 Behavioural changes in the exposed fish. Curling of Spine and vertical movement of the fish due to loss of equilibrium is depicted. Due to complete loss of equilibrium, fish turned upside down and finally died as can be noticed in the picture.

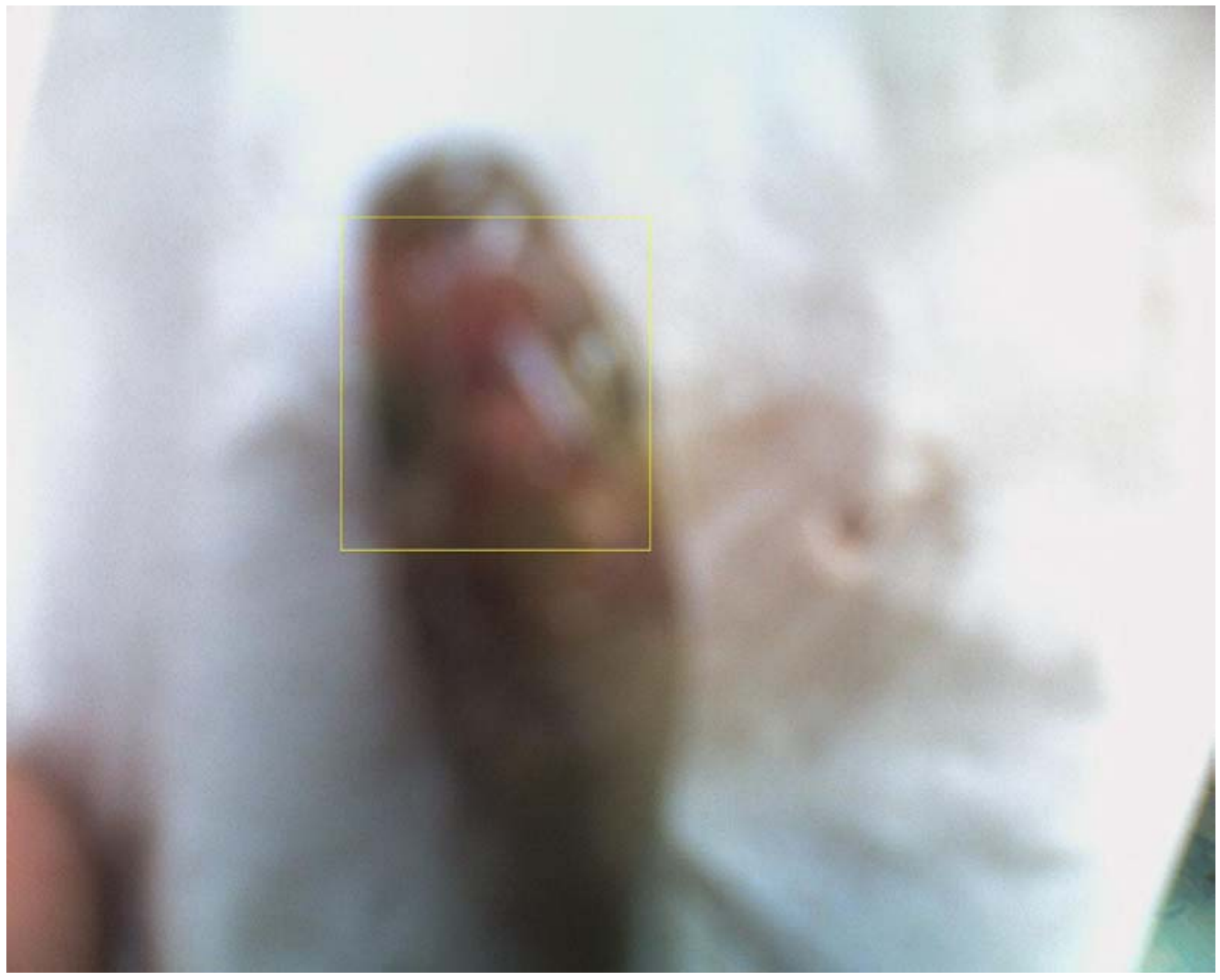

Fig. 5 Haemorrhage in the head region of dead fish exposed to cadmium chloride. When this fish was dissected, haemorrhage was observed around eye orbits.

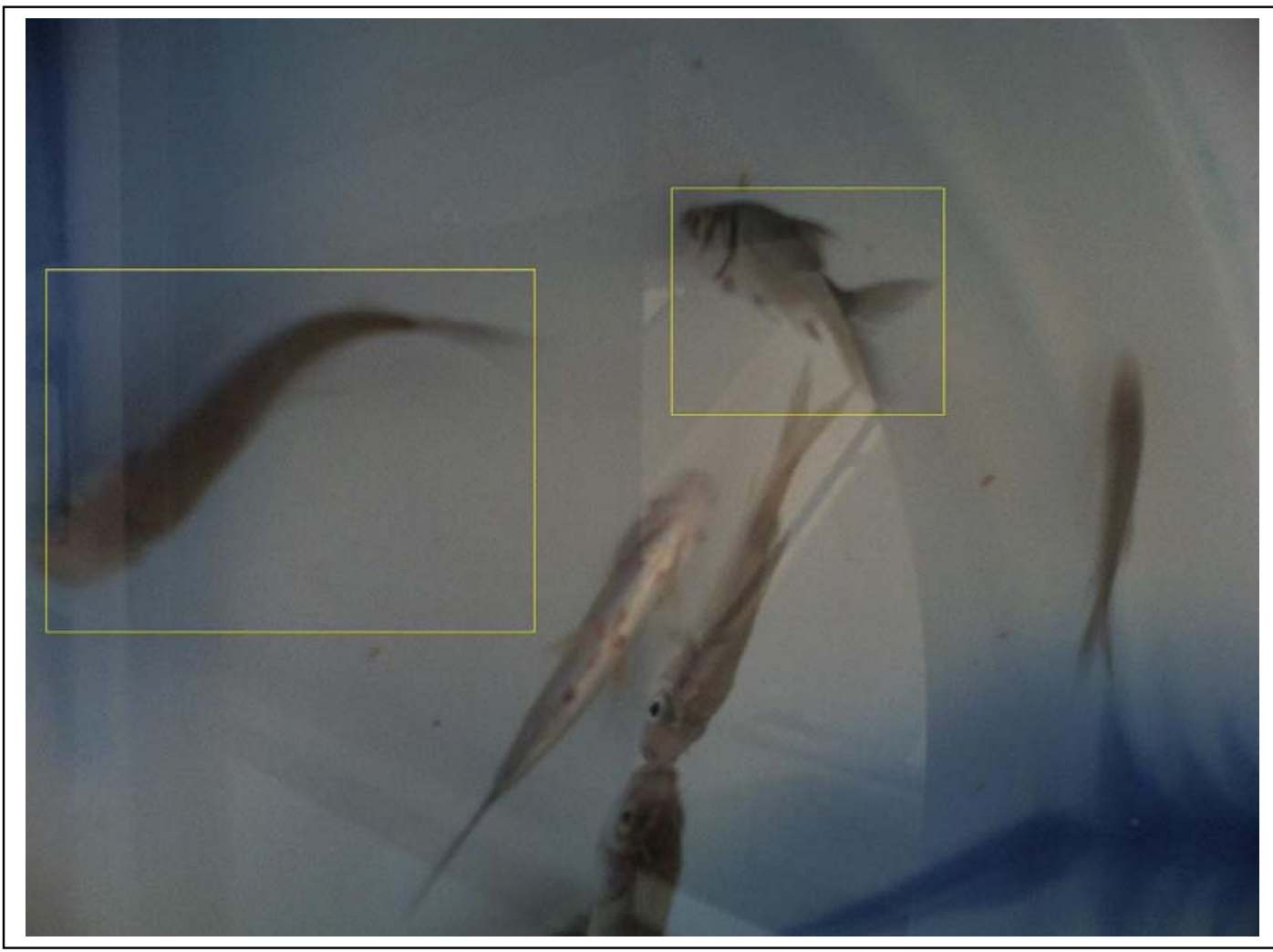


The levels of various biochemical constituents in $\mathrm{mg} / \mathrm{g}$ of the wet tissue in control fish and fish exposed to sub-lethal and lethal doses of cadmium chloride are presented in Table 1 and the changes in terms of percent increase or decrease are given in Table 2. From the data presented, it is clear that at the end of 96-h exposure and exposure to sub-lethal concentration for 7 days, the glucose content of muscle, gill, liver, heart and kidney showed an increase but the increase was not uniform in all the tissues. In case of control fish, biomolecules like glucose, glycogen, total proteins, free aminoacids and lipids of the 5 tissues are in the order: Glucose: $\mathrm{L}>\mathrm{M}>\mathrm{K}>\mathrm{H}>\mathrm{G}$; Glycogen: $\mathrm{L}>\mathrm{M}>\mathrm{K}>\mathrm{G}>\mathrm{H}$; Total Proteins: $\mathrm{M}>\mathrm{L}>\mathrm{K}>\mathrm{H}>\mathrm{G}$; Free aminoacids: $\mathrm{L}=\mathrm{M}=\mathrm{G}=\mathrm{H}=\mathrm{K}$; Lipids: $\mathrm{M}>\mathrm{L}>\mathrm{G}>\mathrm{K}>\mathrm{H}$. The increase in the glucose level of the tissue while decrement in tissue glycogen in exposed fish makes it clear that the glycogen reserves are being used to meet the stress caused. Increase in serum glucose levels in fish under stress was reported by Bedii and Kenan (2005), Chowdhury et al. (2004), Almeida et al. (2001). This can be attributed to several factors and one of them is the decrease in the specific activity of some enzymes like phosphofructokinase, lactate dehydrogenase and citrate kinase that decrease the capacity of glycolysis (Almeida et al., 2001).

Table 1: Changes in the levels of biochemical constituents in the fish, Catla catla exposed to the toxicant Cadmium chloride.

\begin{tabular}{|c|c|c|c|c|}
\hline \multirow[b]{2}{*}{ Organ } & \multicolumn{3}{|c|}{ Exposure } & \multirow[b]{2}{*}{$\begin{array}{l}\text { Biochemical constituents } \\
\text { expressed in } \mathrm{mg} / \mathrm{g} \text { wet } \\
\text { weight of the tissue }\end{array}$} \\
\hline & Control & $\begin{array}{c}\text { Sub-Lethal } \\
\left(1 / 10^{\text {th }} \text { of } 96 \mathrm{~h}-\right. \\
\left.\text { LC }_{50}\right)\end{array}$ & $\begin{array}{c}\text { Lethal } \\
\left(96 \mathrm{~h}-\mathrm{LC}_{50}\right)\end{array}$ & \\
\hline \multirow{5}{*}{ Muscle } & $9.36 \pm 0.54$ & $11.12 \pm 0.54^{* *}$ & $14.64 \pm 1.15^{* * *}$ & Glucose \\
\hline & $6.94 \pm 0.68$ & $6.34 \pm 0.6^{(a)}$ & $5.62 \pm 0.38^{* *}$ & Glycogen \\
\hline & $36.56 \pm 0.67$ & $36.0 \pm 0.28^{(a)}$ & $34.56 \pm 0.67^{* *}$ & Total Proteins \\
\hline & $100.8 \pm 14.8$ & $76.8 \pm 6.6^{*}$ & $56.8 \pm 10.7^{* * *}$ & Lipids \\
\hline & - & - & $36.8 \pm 14.11$ & Free amino acids \\
\hline \multirow{5}{*}{ Gill } & $2.96 \pm 0.54$ & $4.64 \pm 0.88^{* *}$ & $7.28 \pm 0.87^{* * *}$ & Glucose \\
\hline & $5.62 \pm 0.38$ & $5.34 \pm 0.31^{(a)}$ & $4.3 \pm 0.82^{*}$ & Glycogen \\
\hline & $8.72 \pm 0.44$ & $7.68 \pm 0.59^{*}$ & $7.44 \pm 0.60^{* *}$ & Total Proteins \\
\hline & $68.8 \pm 4.38$ & $54.4 \pm 5.36^{* *}$ & $47.2 \pm 6.57^{* * *}$ & Lipids \\
\hline & - & - & - & Free amino acids \\
\hline \multirow{5}{*}{ Liver } & $11.52 \pm 0.44$ & $13.52 \pm 0.66^{* *}$ & $15.12 \pm 0.87^{* * *}$ & Glucose \\
\hline & $9.18 \pm 0.38$ & $7.7 \pm 0.78^{* *}$ & $6.72 \pm 0.82^{* * *}$ & Glycogen \\
\hline & $30.0 \pm 0.49$ & $23.36 \pm 0.60^{* * *}$ & $19.16 \pm 0.67^{* * *}$ & Total Proteins \\
\hline & $91.2 \pm 6.57$ & $74.4 \pm 5.36^{* *}$ & $59.2 \pm 6.57^{* * *}$ & Lipids \\
\hline & - & - & $68.0 \pm 12.7$ & Free amino acids \\
\hline \multirow{5}{*}{ Heart } & $6.08 \pm 0.44$ & $8.16 \pm 0.88^{* *}$ & $9.12 \pm 0.66^{* * *}$ & Glucose \\
\hline & $3.42 \pm 0.42$ & $3.1 \pm 0.34^{(a)}$ & $2.52 \pm 0.34^{*}$ & Glycogen \\
\hline & $14.08 \pm 1.0$ & $11.52 \pm 0.66^{* *}$ & $9.2 \pm 1.13^{* * *}$ & Total Proteins \\
\hline & $49.6 \pm 5.36$ & $35.2 \pm 4.38^{* *}$ & $27.2 \pm 6.57^{@}$ & Lipids \\
\hline & - & - & - & Free amino acids \\
\hline \multirow{5}{*}{ Kidney } & $7.76 \pm 0.36$ & $9.44 \pm 1.00^{* *}$ & $10.72 \pm 0.36^{* * *}$ & Glucose \\
\hline & $6.12 \pm 0.49$ & $5.04 \pm 0.79^{*}$ & $3.56 \pm 0.37^{* * *}$ & Glycogen \\
\hline & $20.96 \pm 0.78$ & $19.04 \pm 0.72^{@}$ & $11.92 \pm 0.59^{* * *}$ & Total Proteins \\
\hline & $52.0 \pm 8.48$ & $\left.42.4 \pm 5.36^{(}\right)$ & $35.2 \pm 4.38^{* *}$ & Lipids \\
\hline & - & - & $78.8 \pm 9.85$ & Free amino acids \\
\hline
\end{tabular}

@: Not significant; * : Significant at $\mathrm{P}<0.05 ; * *$ : Highly significant at $\mathrm{P}<0.01 ; * * *$ : Very highly significant at $\mathrm{P}<0.001$. 
Table 2: Variations in the levels of biochemical constituents in terms of $\%$ increase ( $)$ or $\%$ decrease ( $\nabla$ in $C$. catla exposed to sub-lethal and lethal doses of cadmium chloride as compared to control fish.

\begin{tabular}{|c|c|c|c|c|c|c|c|c|}
\hline \multirow{2}{*}{ Tissue } & \multicolumn{2}{|c|}{ Glucose $(\%)$} & \multicolumn{2}{|c|}{ Glycogen $(\% \downarrow)$} & \multicolumn{2}{|c|}{$\begin{array}{c}\text { Total Proteins } \\
(\% \downarrow)\end{array}$} & \multicolumn{2}{|c|}{ Lipids $(\% \downarrow)$} \\
\hline & \begin{tabular}{|c|} 
Sub- \\
Lethal
\end{tabular} & Lethal & $\begin{array}{c}\text { Sub- } \\
\text { Lethal }\end{array}$ & Lethal & $\begin{array}{c}\text { Sub- } \\
\text { Lethal }\end{array}$ & Lethal & $\begin{array}{c}\text { Sub- } \\
\text { Lethal }\end{array}$ & Lethal \\
\hline Muscle & 18.8 & 6.4 & 8.64 & & 1.53 & 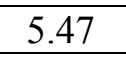 & 23.8 & 43.65 \\
\hline Gill & 56.75 & 145.9 & 4.98 & 23.48 & 11.92 & 14.6 & 20.93 & 31.39 \\
\hline Liver & 17.36 & 31.25 & 16.12 & 26.79 & 22.13 & 36.13 & 18.42 & 35.08 \\
\hline Heart & 21.64 & 38.14 & 9.35 & 41.83 & 18.18 & 34.65 & 29.03 & 45.16 \\
\hline Kidney & 34.21 & 50.0 & 17.64 & 41.83 & 9.16 & 43.12 & 18.46 & 32.3 \\
\hline
\end{tabular}

Glycogen levels are found to be highest in liver, as it is the chief organ of carbohydrate metabolism in animals, followed by muscle. Liver glycogen is concerned with storage and export of hexose units for maintenance of blood glucose and that of muscle glycogen is to act as a readily available source of hexose units for glycolysis within the muscle itself. A fall in the glycogen level clearly indicates its rapid utilization to meet the enhanced energy demands in fish exposed to toxicant through glycolysis or Hexose Monophosphate pathway. It is assumed that decrease in glycogen content may be due to the inhibition of hormones which contribute to glycogen synthesis. Decrease in liver and muscle glycogen levels is in corroboration with the reports of earlier workers (Bedii and Kenan, 2005; Dubale and Punita shah, 1981; Sastry and Subhadra, 1984). The order of depletion of glycogen reserves is $\mathrm{K}>\mathrm{L}>\mathrm{H}>\mathrm{M}>\mathrm{G}$ in fish exposed to sub-lethal dose while the order changed to $\mathrm{K}>\mathrm{L}>\mathrm{H}>\mathrm{G}>\mathrm{M}$ in fish exposed to lethal dose of the toxicant. This could be because the gills utilize glycogen reserves rapidly to meet the respiratory stress when exposed to the lethal concentration.

Muscle rich in proteins, forms mechanical tissue intended for mobility and do not participate in metabolism. Liver being the centre for various metabolisms is also rich in proteins. In all the tissues of the exposed fish, the total protein content was found to be reduced. The order of decrease in different tissues when exposed to sub-lethal dose was observed to be $\mathrm{L}>\mathrm{H}>\mathrm{G}>\mathrm{K}>\mathrm{M}$ while exposure to lethal concentration changed the order to $\mathrm{K}>\mathrm{L}>\mathrm{H}>\mathrm{G}>\mathrm{M}$. This suggests the fact that the higher levels of the toxicant affect the kidneys while lower levels affect the liver. The decrease in the protein content as observed in the present study in most of the fish tissues may be due to metabolic utilization of the ketoacids to gluconeogenesis pathway for the synthesis of glucose, or due to directing the free aminoacids for the synthesis of proteins, or for the maintenance of osmo and ionic regulation (Schmidt Nielson, 1975). It could also be due to the production of heat shock proteins or destructive free radicals or could be a part of heavy metal induced apoptosis.

Free aminoacids were not detected in the tissue of control as well as fish exposed to sub-lethal concentration. But they were detected in the muscle, liver and kidney tissues of the fish exposed to the lethal concentration and not in the gills or heart. This can be presumed to be an indication of acute effect of the lethal concentration of cadmium on those tissues. De smet and Blust (2007) has reported that proteolysis is intended to increase the role of proteins in the energy production during cadmium stress. 
Lipids are also the storage form of energy like glycogen. The lipid levels also decreased in the tissues of the fish exposed to the sub-lethal and lethal concentration of cadmium chloride. Effect of cadmium on the lipid content was reported by earlier investigators (Levesque et al., 2002; Dubale and Punita shah, 1981; Fabien Pierron et al., 2007). The decrease in the lipid level is as $\mathrm{H}>\mathrm{M}>\mathrm{G}>\mathrm{K}>\mathrm{L}$ in fish exposed to sub-lethal dose and the order is $\mathrm{H}>\mathrm{M}>\mathrm{L}>\mathrm{K}>\mathrm{G}$ in fish exposed to lethal dose.

\section{CONCLUSIONS}

Acute toxicity studies of Cadmium on the edible carp, Catla catla revealed significant changes in the biochemical constituents of the fish like glucose, glycogen, total proteins, lipids and free aminoacids. Haemorrhagic conditions observed in the dead fish clearly indicate the toxic effect of cadmium. The fish which were previously exposed to lower concentrations of heavy metals have better resistance to higher concentrations of these heavy metals. This might be due to the adaptive response which is characteristic of vertebrates. Also, the adults are found to be more susceptible to the toxicant than the fingerlings. Unlike organic pollutants, these heavy metals cannot be biodegraded. Even though some of the micro-organisms can be used for the biosorption, the higher concentrations of these metals are toxic to those micro-organisms even. This process is specific and depends on the cell wall composition of the micro-organism. More work should be carried out to identify and employ the useful strains of microbes for effective removal of the heavy metal toxicants so that cultured fish with high nutritive value could safely be utilized for human consumption.

\section{ACKNOWLEDGEMENTS}

We express our sincere thanks to the Management of the Bapatla Education Society for their continued encouragement and support. We also express our deep sense of gratitude to Sri J. S. Rao, Head of the Department, and Prof. G. N. Rao, Principal of the Bapatla College of Engineering, Bapatla for having provided us the laboratory facilities and the moral support.

\section{REFERENCES}

1. Almeida JA, Novelli EL, Dal Pai Silva M, Junior RA 2001. Environmental cadmium exposure and metabolic responses of the Nile tilapia, Oreochromis niloticus. Environ Pollut. 114 (2): 169-!75.

2. Arno Kaschl, Volker Römheld and Yona Chen 2002. Cadmium binding by fractions of dissolved organic matter $\&$ humic substances from municipal solid waste compost. J.Environ.Qual. 31:1885-1892.

3. Audry S, Schafer J, Blanc G, Jouanneau JM 2004. Fifty-year sedimentary record of heavy metal pollution $(\mathrm{Cd}, \mathrm{Zn}, \mathrm{Cu}, \mathrm{Pb})$ in the Lot River reservoirs (France). Environ Pollut. 132(3):413-426.

4. Bedii CiCiK and Kenan ENGiN 2005. The effects of Cadmium on levels of glucose in serum and glycogen reserves in the liver and muscle tissues of Cyprinus carpio(L., 1758); Turk.J.Vet.Anim.Sci., (29): 113-117.

5. BR Kiran, TR Shashi Shekhar, ET Puttaiah and Y Shivaraj 2006. Trace metal levels in the organs of Finfish Oreochromis mossambicus (Peter) and relevant water of Jannapura lake, India. Journal Environ.Science \& Engg. 48(1): 15-20.

6. Brown DA, Bay SM, Alfafara JF,Hershelman GP and Rosenthal KD 1984. Detoxification/toxification of cadmium in scorpionfish (Scorpaena guttata): Acute exposure. Aquatic Toxicol. 5(2): 93-107. 
7. Bryan GW and Langston WJ 1992. Bioavailability, accumulation and effects of heavy metals in sediments with special reference to United Kingdom estuaries: A Review. Environmental Pollution. 76 (2): 89-131.

8. Chowdhury MJ, Pane EF, Wood CM 2004. Physiological effects of dietary cadmium acclimation and waterborne cadmium challenge in rainbow trout: respiratory, ionoregulatory, and stress parameters. Comp Biochem Physiol C Toxicol Pharmacol., 139(1-3): 163-173.

9. Chrastny V, Komarek M, Tlustos P, Svehla J 2006. Effects of flooding on lead and cadmium speciation in sediments from a drinking water reservoir. Environ Monit Assess., 118(1-3): 113-123.

10. De Smet H, Blust R 2001. Stress responsed and changes in protein metabolism in carp Cyprinus carpio during cadmium exposure. Ecotoxicol Environ Saf., 48(3): 255262.

11. Dubale MS and Punita shah 1981. Biochemical alterations induced by cadmium in the liver on Channa punctatus. Environmental research. 26 (1):110-118.

12. Dupler D 2001. Heavy metal poisoning. Gale Encyclopedia of Alternative Medicine. Farmington Hills, MI: Gale Group.

13. Fabien Pierron, Magalie Baudrimont, Angélique Bossy, Jean-Paul Bourdineaud, Daniel Brèthes, Pierre Elie and Jean-Charles Massabuau 2007. Impairment of lipid storage by cadmium in the European eel (Anguilla anguilla). Aquatic Toxicology. 81(3): 304-311.

14. Finney DJ 1971. Probit Analysis, Cambridge University Press. $3^{\text {rd }}$ Edition.

15. Forstner U and Prosi F 1979. Heavy metal pollution in freshwater ecosystem. In "Biological aspects of Freshwater Pollution" : In O. Ravera (ed.), Pergamon Press, Oxford) 129-161.

16. Jarrup L 2003. Hazards of heavy metal contamination. Br Med Bull, 68:167-182.

17. Kemp A, Adrienne JM, Kits Van Hejningen 1954. A colorimetric method for the determination of glycogen in tissues. The Biochemical Journal (56): 640-648.

18. Levesque HM, Moon TW, Campbell PGC and Hontela A 2002. Seasonal variation in carbohydrate and lipid metabolism of yellow perch (Perca flavescens) chronically exposed to metals in the field. Aquatic Toxicology. 60(3-4): 257-267.

19. Lide D 1992. CRC Handbook of Chemistry and Physics. $73^{\text {rd }}$ Edition. Boca Raton, FL: CRC Press.

20. Lowry OH, Rosenbrough NJ, Farr RL, Randall RJ 1951. Protein measurement with the Folin Phenol reagent. J.Biol.Chem.,(193): 265-275.

21. Luo SQ, Plowman MC, Hopfer SM, Sunderman FW Jr 1993. Mg (2+) deprivation enhances and $\operatorname{Mg}(2+)$ supplementation diminishes the embryotoxic and teratogenic effects of $\mathrm{Ni} 2+, \mathrm{Co} 2+, \mathrm{Zn} 2+$ and $\mathrm{Cd} 2+$ for frog embryos in the FETAX assay. Ann Clin Lab Sci. 23(2):121-129.

22. Mehmet Yilmaz, Ali Gül and Erhan Karaköse 2004. Investigation of acute toxicity and the effect of cadmium chloride $(\mathrm{CdCl} 2 \cdot \mathrm{H} 2 \mathrm{O})$ metal salt on behavior of the guppy (Poecilia reticulata). Chemosphere. 56 (4): 375-380.

23. Moore S and Stein WH 1954. A modified ninhydrin reagent for the photometric determination of amino acids and related compounds: J.Biol.Chem., (221): 907

24. Pande SV, Parvin Khan A, Venkatasubramanium TA 1963. Microdetermination of lipids and serum fatty acids. Analyt. Biochem. 6 (5): 120-125. 
25. Rashed MN 2001. Cadmium and lead levels in fish (Tilapia nilotica) tissues as biological indicator for lake water pollution. Environ Monit Assess: 68(1): 75-89.

26. Roberts JR 1999. Metal toxicity in Children. Training Manual on Pediatric Environmental Health: Putting It into Practice. Emeryville, CA: Children's Environmental Health Network.

27. Sastry KV and Subhadra K 1982. Effect of cadmium on some aspects of carbohydrate metabolism in a freshwater catfish, Heteropneustes fossilis. Toxicol. Lett. 14: 45-55.

28. Schmidt Nielson B 1975. Osmoregulation: Effect of Salinity and heavy metal. Fed. Proc. 33: 2137-2146.

29. Seebaugh DR, Goto D, Wallace WG 2005. Bioenhancement of cadmium transfer along a multi level food chain. Mar Environ Res. 59(5): 473-491.

30. Sunderman FW Jr., Plowman MC, Hopfer SM 1991. Embryotoxicity and teratogenicity of cadmium chloride in Xenopus laevis, assayed by the FETAX procedure. Ann. Clin. Lab Sci, 21(6): 381-391.

31. Waisberg M, Joseph P, Hale B and Beyersmann D 2003. Target for Toxicity and Death due to Exposure to Cadmium. Chloride. Toxicology. 192(2-3): 95-117.

32. Wright DA and Frain JW 1981. The effect of calcium on cadmium toxicity in the freshwater amphipod, Gammarus pulex (L.). Arch. Environ. Contam. Toxicol., 10(3):321-328.

33. Zanders IP and Rojas WE 1996. Salinity effects on cadmium accumulation in various tissues of the tropical fiddler crab Uca rapax. Environmental Pollution, 94(3): 293299. 